\title{
Essential Oil and Fatty Acid Composition and Antioxidant Capacity and Total Phenolic Content of Parsley Seeds (Petroselinum crispum) Grown in Hatay Region
}

\author{
Ahmet Mert ${ }^{1}$, Mahir Timur ${ }^{2 *}$ \\ Mustafa Kemal Univ, faculty of agriculture, Hatay,TURKEY. \\ Mustafa Kemal Univ, Altınözü Vocational School, Department of Food Process, Hatay, TURKEY.
}

\begin{abstract}
The aim of the present study was to investigate the essential oil and fatty acid compositions and antioxidant capacity and total phenolic content of parsley seeds grown in Arsuz/ hatay region. Parsley seeds had a moisture content of $12,6 \mathrm{wt} . \%$ and ash content of 6,86 wt. \% while the essential oil content of 2,52 wt. \% and total lipid content of $8,85 \mathrm{wt} . \%$. The essential oil was analyzed by gas chromatography and thirty two volatile compounds were determined. The composition of fatty acids were also investigated by GC and seven content were determined. The seeds were extracted with methanol for determination of antioxidant capacity and total phenolic content. Total phenol concentration was found $67.25 \pm 5.9 \mathrm{mg}$ gallic acid equivalent $/ \mathrm{g}$ of extract powder. DPPH free radical-scavenging activity $\mathrm{IC}_{50}$ was found as $0,523 \pm 12 \mathrm{mg} / \mathrm{ml}$. From the Trolox calibration curve cupric reducing antioxidant capacity TEACCUPRAC:17,95 $\mu \mathrm{g} / \mathrm{mL}$ was found. Results were compared with standard antioxidant compound BHA and BHT.
\end{abstract}

Key words: Parsley seed, Essential oil, Fatty acid, Antioxidant activity, Phenolic content.

\section{INTRODUCTION}

Parsley (Petroselinum crispum) is a species of Petroselinum in the family Apiaceae, in Europe and in the Mediterranean region (Italy, Greece, Algeria, and Tunisia), and widely cultivated as a herb, a spice, and a vegetable. ${ }^{1}$ Parsley was traditionally used in making tea for treating gallstones and dysentery. The leaves, seeds and roots of Parsley were used in treating numerous digestive problems including diarrhea, ulcer, flatulence and colic pain. ${ }^{1}$

Parsley seeds contain an essential oil, composed mainly of myristicin, apiole, and 2,3,4,5-tetramethoxyallylbenzene (3-methoxy- $\gamma$-asarone) and, that is responsible for the pronounced odor and flavor of parsley. ${ }^{2}$

Because of the side effects of synthetic preservatives people have preferred to the use of natural products instead of to customary preservatives in the last few decades.
As a result of these, consumers interested to natural products, inclusive particularly plant extracts and their essential oils. Spices and herbs have been added to foods to enhance the flavor, color and aroma of foods. As well as they are also known for their preservative and medicinal value. ${ }^{3}$

Sources of natural antioxidants are primarily plant phenolics that may occur in all parts of plants such as fruits, vegetables, nuts, seeds, leaves, root, and barks. ${ }^{4}$

Antimicrobial and antioxidant activities of plants may be due to a variety of different ingredients, including peptides, aldehydes, alkaloids, essential oils, phenols and other soluble constituents. Then these plants have been found to be compounds that are an important therapeutic application against human pathogens. ${ }^{5,6}$
DOI: 10.5530/ijper.51.3s.63 Correspondence: Mahir Timur,

Mustafa Kemal Univ, Altinözü Vocational School, Dep. of Food Process, Hatay, TURKEY.

Phone no: +90 5055451372 Email Id : emahirtimur@ gmail.com 
Among the natural compounds, the phenolic compounds constitute one of the major groups of active principles acting as radical scavengers and antioxidants. ${ }^{7}$ The harmful action of free radicals can be blocked by antioxidant substances, which scavenge the free radicals and detoxify the organism. ${ }^{8,9}$ The search for newer natural antioxidants, especially of plant origin, has been increasing ever since. Today many people prefer to use medicinal plants rather than chemical drugs.

In this paper the essential oil and fatty acid composition of parsley seeds were determined and antioxidant capacity and total phenolic content of methanol extract was screened.

\section{MATERIAL AND METHODS}

\section{Extraction and GC analysis of essential oil}

The air-dried and ground seeds were submitted for $3 \mathrm{~h}$ to water-distillation using Clevenger apparatus. The obtained essential oil was dried over anhydrous sodium sulphate and after filtration, stored at $4^{\circ} \mathrm{C}$ until analyzed. GC-MS analysis was performed on a HP6890 gas chromatography instrument. The analytes were separated on a HP-5MS nonpolar capillary column.

\section{Extraction and GC analysis of seed oil}

Chemical extraction of seed oil from ground seeds was carried out with soxhlet apparatus by using petroleum ether as solvent. The total extraction process was completed within four hours. The extracted phase was filtered and concentrated to vacuum under reduced pressure in rotary evaporator and dried in desiccators.

The fatty acid composition of seed oil was determined by gas chromatography of the methyl esters using a HP $6890 \mathrm{~N}$ gas chromatograph integrated hp Innovax column. ${ }^{10}$

\section{Methanolic extract}

Parsley seeds were powdered by electric blender. Approximately $100 \mathrm{~g}$ of powder was added to $400 \mathrm{ml}$ methanol and soaked for $2 \mathrm{~h}$ at $40{ }^{\circ} \mathrm{C}$. This process was repeated ten times. Removal of the powder from solvent was done by filtration and the filtrate was concentrated using a rotary evaporator at $40{ }^{\circ} \mathrm{C}$ and extract was stored at $-4^{\circ} \mathrm{C}$ until analyzed for antioxidant activity.

\section{Determination of total phenolic content}

The total phenolic content of the extract was determined by the Folin-Ciocalteau method. ${ }^{11,12}$ Estimations were carried out in triplicate and calculated from a calibration curve obtained with gallic acid. Total phenolic concentrations were expressed as gallic acid equivalents
( $\mu \mathrm{g}$ GAE/mL methonolic solution). The absorbances of all samples were measured at $765 \mathrm{~nm}$.

\section{DPPH radical-scavenging activity}

The free radical scavenging activity of the methanolic extract of parsley seeds was measured in terms of hydrogen donating or radical scavenging ability using the stable DPPH radical method. ${ }^{13}$ The DPPH solution $\left(6 \times 10^{-5} \mathrm{~mol} / \mathrm{L}\right)$ in methanol was prepared and $3,75 \mathrm{ml}$ of this solution was added to $1,25 \mathrm{ml}$ of extract solution (or standard) in methanol at different concentrations $(0,4-0,025 \mu \mathrm{g} / \mathrm{mL})$. After 30 minutes of incubation at $40^{\circ} \mathrm{C}$ in a thermostatic bath, the decrease in the absorbance ( $\mathrm{n}=3$ ) was measured at $517 \mathrm{~nm}$. The same procedure was repeated with synthetic antioxidant, BHT and BHA, as positive control and a blank. Inhibition level (measured as percentage, I \%) of the free radical.

The percent DPPH scavenging ability was calculated as follows:

$\mathrm{I} \%=\left(\mathrm{A}_{\text {blank }}-\mathrm{A}_{\text {sample }} / \mathrm{A}_{\text {blank }}\right) \times 100$

where $A_{\text {blank }}$ is the absorbance of the control reaction (containing all reagents except the test compound) and A sample is the absorbance of the test compound. The extract concentration required for $50 \%$ inhibition $\left(\mathrm{IC}_{50}\right)$ was calculated from the graph by plotting inhibition percentage against extract concentration. Tests were carried out in triplicate and BHT and BHA were used as positive controls

\section{CUPRAC assay of total antioxidant capacity}

The total antioxidant capacity was determined by the CUPRAC method. ${ }^{14}$ Estimations were carried out in triplicate and calculated from a calibration curve obtained with TROLOX . Total antioxidant concentrations were expressed as $\mathrm{mmol} \mathrm{TR} / \mathrm{g}$ dry matter. The absorbances of all samples were measured at $450 \mathrm{~nm}$.

\section{RESULTS \& DISCUSSION}

In the steam distillation of Parsley seeds two volatile oils were obtained, one of which was light from water and one of which was heavy from water. The color of the volatile oil is very pale yellow with a total yield of $2.52 \%$ $(\mathrm{w} / \mathrm{w})$. The yield was based on the dry weight of seeds. The volatile oil constituents and their percentages are listed according to their elution order on hp 5 capillary column in Table 1. In the light oil, twenty two components were identified that represented $96.86 \%$ of the oil and in the heavy oil, thirty two components were identified that represented $94.56 \%$ of the oil . The volatile oil consists of mainly aliphatic esters, alcohols and hydrocarbons. The major components of the volatile oil are 


\begin{tabular}{|c|c|c|c|}
\hline Peak no & Component & $\%$ (light) & $\%($ heavy) \\
\hline 1 & Alpha-pinene & 2,52 & 14.96 \\
\hline 2 & Camphene & - & $\operatorname{tr}$ \\
\hline 3 & Beta-pinene & 2,37 & 13.03 \\
\hline 4 & Sabinene & $\operatorname{tr}$ & 0.9 \\
\hline 5 & Alpha-Phellandrene & $\operatorname{tr}$ & $\operatorname{tr}$ \\
\hline 6 & Beta myrcene & $\operatorname{tr}$ & $\operatorname{tr}$ \\
\hline 7 & Limonene & $\operatorname{tr}$ & tr \\
\hline 8 & Beta phellandrene & 1.33 & 5.83 \\
\hline 9 & Gamma terpinene & $\operatorname{tr}$ & tr \\
\hline 10 & Cymene & - & $\operatorname{tr}$ \\
\hline 11 & İsopropenyl tolüene & - & $\operatorname{tr}$ \\
\hline 12 & Terpinolene & - & tr \\
\hline 13 & Adamantane & - & $\operatorname{tr}$ \\
\hline 14 & 4-(1,2,4-triazole-1-yl)phenol & - & $\operatorname{tr}$ \\
\hline 15 & Alpha bergamotene & - & tr \\
\hline 16 & Caryophyllene & - & $\operatorname{tr}$ \\
\hline 17 & Myrtenal & $\operatorname{tr}$ & 1.13 \\
\hline 18 & Beta cubebene & - & $\operatorname{tr}$ \\
\hline 19 & Beta farnesene & $\operatorname{tr}$ & tr \\
\hline 20 & 2-vinyl-2-butenal & - & tr \\
\hline 21 & Alpha cubebene & $\operatorname{tr}$ & $\operatorname{tr}$ \\
\hline 22 & Alpha ocimene & $\operatorname{tr}$ & $\operatorname{tr}$ \\
\hline 23 & Alpha himachalene & $\operatorname{tr}$ & $\operatorname{tr}$ \\
\hline 24 & 2-ethyl-2-hexanal & - & $\operatorname{tr}$ \\
\hline 25 & Beta sesquiphellanderene & - & $\operatorname{tr}$ \\
\hline 26 & Carotol & $\operatorname{tr}$ & 0.95 \\
\hline 27 & Levojunenol & - & tr \\
\hline 28 & 3-methoxy- $y$-asarone & 34.19 & 21.82 \\
\hline 29 & Elemicin & 5.09 & 3.33 \\
\hline 30 & Myristicin & 23.83 & 16.72 \\
\hline 31 & Methoxyeugenol & $\operatorname{tr}$ & $\operatorname{tr}$ \\
\hline 32 & Apiol & 27.53 & 17.02 \\
\hline
\end{tabular}

tr:Trace $(<0.6 \%)$

3-methoxy- $\gamma$-asarone, apiol, myristicin, alpha-pinene, beta pinene and beta-phellandrene respectively.

Parsley seed oil extracted by soxhlet extraction apparatus using petroleum ether as solvent and yield obtained $8,85 \mathrm{wt} . \%$. The yield was based on dry weights of milled seeds. The seed oil constituents and their percentages are listed in Table 2 according to analyses the composition of volatile oil and fixed oil is similar and major components are 3-methoxy- $\gamma$-asarone, myristicin and apiol respectively.

The total phenolic content was 67.25 5.9 mg gallic acid equivalent/g of extract powder in reference to the standard curve $\left(\mathrm{y}=1,9409 \mathrm{x}+0,0032, \mathrm{r}^{2}=0,9996\right)$.

\begin{tabular}{|c|c|c|}
\hline \multicolumn{3}{|c|}{ Table 2: The seed oil constituents of Parsley seeds } \\
\hline Peak no & Compound & $\%$ \\
\hline 1 & 3-methoxy-y-asarone & 26,93 \\
\hline 2 & Palmitic acid & 1,31 \\
\hline 3 & Elemicin & 0,85 \\
\hline 4 & Myriticin & 13,48 \\
\hline 5 & Stearic acid & 0,43 \\
\hline 6 & Oleic acid & 25,91 \\
\hline 7 & Apiol & 30,38 \\
\hline
\end{tabular}

\section{DPPH radical-scavenging activity}

$\mathrm{IC}_{50}$ for DPPH radical-scavenging activity was 0,52312 $\mathrm{mg} / \mathrm{ml}$. The $\mathrm{IC}_{50}$ values for BHA and BHT were 0,022 0.11 , and $0,0570.07 \mathrm{mg} / \mathrm{ml}$, respectively. According to the results the parsley seeds revealed the poor antioxidant properties.

From the Trolox calibration curve CUPRAC activity TEACCUPRAC:17,95 $\mu \mathrm{g} / \mathrm{mL}$ was found.

\section{CONCLUSION}

We have determined that the essential oil and fatty acid composition and antioxidant capacity and total phenolic content of parsley seeds (petroselinum crispum) which is grown in Hatay region for better pharmacognostical knowledge of the parsley seed. It is obvious that the obtained results shows that parsley seeds have poor antioxidant activity than synthetic antioxidants BHT (Butylated Hydroxytoluene) and BHA (Butylated Hydroxanisole). Nowadays, as the tendency of natural treatment methods increases, the composition of medicinal and aromatic plants should be determined and their use efficiency will be increased according to active compounds.

\section{ACKNOWLEDGEMENT}

None

\section{CONFLICT OF INTEREST}

None

\section{ABBREVIATION USED}

GC: Gas chromatography; DPPH: 2,2-diphenyl1-picrylhydrazyl; TEACCUPRAC: Torolox Equivalent Cupric Reducing Antioxidant Capacity; BHA: Butylated Hydroxanisole; BHT: Butylated Hydroxytoluene; GAE: Gallic Acid Equivalent; I: Inhibition; A: Absorbance. 


\section{REFERENCES}

1. Bauer K, Garbe D, Surburg H. Common Fragrance and Flavor Materials. $4^{\text {th }}$ ed. Weinheim: Wiley VCH. 2001;189.

2. Simon JE, Quinn J. Characterization of Essential Oil of Parsley, J. Agric. Food Chem. 1988; 36(3):467-72.

3. Wu YY, Li W, Xu Y, Jin EH, Tu YY. Evaluation of the antioxidant effects of four main theaflavin derivatives through chemiluminescence and DNA damage analyses. J Zhejiang Univ Sci B. 2011;12(9):744-51.

4. Yakoob AT, Tajuddin NB, Mathew S, Hussain MIM, Qadri I. Gc-Ms Analysis of Ethanolic Stem Extract of Clausena anisata (Willd.) Hook F Ex Benth. Pharmacognosy Journal. 2016;8(6):576-8.

5. Moldovan RI, Oprean R, Benedec D, Hanganu D, Duma M, Oniga I, et al. LCMS Analysıs, Antıoxıdant And Antımıcrobıal Actıvitıes For Five Specıes Of Mentha Cultıvated In Romanıa. Dig J Nanomater Biostruct. 2014;9(2):559-66.

6. Nickavar B, Alinaghi A, Kamalinejad M. Evalution of the antioxidant properties of five Mentha species. Iran. J. Pharm. Res. 2008;7(3):203-9.

7. Halliwell B, Gutteridge JMC, Cross CE. Free radicals, antioxidants and human disease: where are we now? J. Lab. Clin. Med. 1992:119(6):598-620.
8. Cao GH, Sofic E, Prior RL. Antioxidant capacity of tea and vegetables. J. Agri. Food Chem. 1996;44:3426-31.

9. Wang $\mathrm{H}, \mathrm{Cao} \mathrm{GH}$, Prior RL. Total antioxidant capacity of fruits. J. Agr. Food Chem. 1996:44;701-5.

10. Kaewpiboon C, Winayanuwattikun $\mathrm{P}$, Yongvanich $\mathrm{T}$, Phuwapraisirisan $\mathrm{P}$, Assavalapsakul W. Effect of three fatty acids from the leaf extract of Tiliacora triandra on P-glycoprotein function in multidrug-resistant A549RT-eto cell line. Phcog Mag. 2014;10(Suppl S3):549-56

11. Singleton VL, Rossi JR. Colorimetry of total Phenolics with PhosphomolybdicPhosphotungstic Acid Reagents. Am J Enol. Vitic. 1965:16(3):144-58.

12. Zheleva-Dimitrova D, Nedialkov P, Kitanov G. Radical scavenging and antioxidant activities of methanolic extracts from Hypericum species growing in Bulgaria. Phcog Mag. 2010;6:74-8.

13. Ozgen M, Scheerens JC, Reese RN, Miller RA. Total phenolic, anthocyanin contents and antioxidant capacity of selected elderberry (Sambucus canadensis L.) accessions. Phcog Mag. 2010;6(23):198-203.

14. Apak R, Güçlü K, Özyürek M, Karademir SE, Erçağ $E$, The cupric ion reducing antioxidant capacity and polyphenolic content of some herbal teas, Int J of Food Sci and Nutr. 2006;57(5/6):292-304.

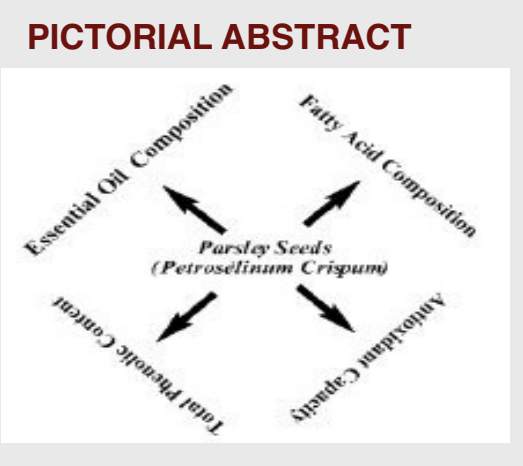

About Authors

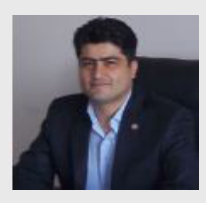

Dr. Mahir TIMUR: He is an assistant professor on oganic chemistry. His area of interests mainly involve organic chemistry, organic synthesis, screening different plant extracts and their isolates for their potential pharmacological activity.

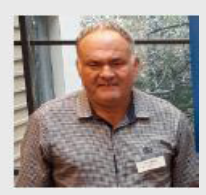

Dr. Ahmet MERT: He is an assistant professor at Department of Medical Plants. His area of interests mainly involve screening different plants.

Cite this article: Mert A, Timur M. Essential Oil and Fatty Acid Composition and Antioxidant Capacity and Total Phenolic Content of Parsley Seeds (Petroselinum crispum) Grown in Hatay Region. Indian J of Pharmaceutical Education and Research. 2017;51(3)Suppl:S437-40. 